\title{
The Development of Formal Ceremonial Coronation Attire of Seri Paduka Baginda yang di-Pertuan Agong From I-XIV Starting From 1957 untill 2016.
}

\author{
Nor Idayu binti Ibrahim \\ University Technology MARA (UiTM), Shah Alam \\ email: idayuibrahimy@gmail.com
}

\begin{abstract}
There is specific formal attire wear by "Seri Paduka Baginda Yang di-Pertuan Agong". The exploration related with Malaysia royal institution and royal etiquettes are aspiring, interesting and there are numbers of printed publications had discovered in depth, onto this fields. Unfortunately, most of them have not yet discovered in-depth research about the development of formal ceremonial coronation attire of "Seri Paduka Baginda Yang diPertuan Agong". The purpose of this paper is to discover the development of ceremonial coronation attire and to document the knowledge regarding the research paper topic. Meyer Schapiro theory of style is used in this research equivalent to feature its style and design of the ceremonial coronation attire. Method applied was the qualitative method because it is the suitable approach to gathering valid data from the experience experts. It is also discussed on the style, muskat and the design of ceremonial attires of them. The coronation attire also known as Royal Regalia. The items are Tengkolok di-Raja, Pending di- Raja, Short Keris and Long Keris. Finally, this research hopefully will benefit and provide a vital source of references to the Malay civilization, researchers, academicians, scholars, students, cultural activist, and also Malaysian regarding with the formal coronation ceremonial attire of "Seri Paduka Baginda Yang di- Pertuan Agong" especially back dated during the period of 1957 until 2016.
\end{abstract}

Keywords: Coronation ceremonial attire, muskat, style, design.

\section{INTRODUCTION}

Seri Paduka Baginda yang di-pertuan Agong is the highest ruler in Malaysia. Their ruler cycle rotate every five years of throne. Clothing is needed of each individual, regardless of status and position. Clothing is required in every activities of life, from the official ceremony to normal activities. Each activities tend to have different type of clothing that suit in different agenda. Clothes can be to wrap up the naked body from any element that could hurt body, adjust their body temperature with the fluctuate weathers, keep their dignity and pride and also give the comfy to the wearer by Zubaidah Shawal (1994). The royalty's family and traders, they are taught to adorn beautiful clothes from the early ages. Their costumes, are adapted from the foreign elements such 
as wearing robes, wore coat made of satin and brocade textiles with striking fabric color. They also wear headdress with velvety materials ornamented with golds, and also wearing headband of gold thread, Zubaidah (1994). This shows that, the Royalties attire had been influence and been adapted from the out reign civilization. Their clothes made from luxury fabrication that are high in quality and beauty. But yet, the Malay identities can be trace from these costumes by observing thru the ornaments and the detailing.

\section{AIM}

To discover the development of formal ceremonial coronation attire of "Seri Paduka Baginda Yang Di-pertuan Agong from I - XIV" from 1957 until 2016.

\section{OBJECTIVES}

To explore the style that had been use for the ceremonial attire of "Seri Paduka Baginda Yang Di-pertuan Agong from I - XIV" from 1957 until 2016 and to document the knowledge regarding this research topic.

\section{SIGNIFICANCE}

This research will oblige as an informative documentation to the academicians and historians that can be directed as a reference guide. Researchers may refer to this study and find other lacking data and be inspired to dig more on the "Seri Paduka Baginda Yang Di-Pertuan Agong" related to the Royal Institution Tradition and Customs. This heritage knowledge that being inherited to the lovers can be preserved and persist for the upcoming generations.

\section{RESEARCH QUESTION}

What is the specific style for the formal coronation attire of "Seri Paduka Baginda Yang Di-pertuan Agong?

\section{RESEARCH METHODOLOGY}

Method of qualitative, based on semi-structure questions to selected respondents. The analysis of the finding been analyse by applying an art theory by Meyer Schapiro the theory of Style.

\section{LITERATURE REVIEW}

"Seri Paduka Baginda Yang Di-pertuan Agong" is a representative from several states in Malaysia. According to Abdul Aziz Bari in his book entitled "Majlis Raja-raja; kedudukan dan Peranan dalam Perlembagaan Malaysia" (2003), the federal constitution stipulates that a king was eligible to be elected as the "Yang Dipertuan Agong" with several issues that must be consider, of 1) unless if he is not adult, 2) he told the "Penyimpan Mohor Besar Raja-raja" that he does not intend to be selected as "Yang Di-pertuan Agong", and 3) "Majlis Raja-raja" has adopted a resolution that he was not fit to run the tasks of "Seri Paduka Baginda Yang Di- 
pertuan Agong" due to infirmity of mind or physical or else for other reasons. The selection of "Yang Di-pertuan Agong" is confidential. After the selection occurred, "Yang Di-Pertuan Agong" must be on duty for five years and the cycle keeps rotating for every five years.

Table 1: List of Seri Paduka Baginda Yang di-Pertuan Agong

\begin{tabular}{|l|l|}
\hline No & Details \\
\hline 1 & $\begin{array}{l}\text { Negeri Sembilan } \\
\text { 31 August 1957 - 1 April 1960 } \\
\text { Seri Paduka Baginda Almarhum Tuanku Abdul Rahman ibni } \\
\text { Almarhum Tuanku Muhammad } \\
\text { (24.8.1895-1.4.1960) }\end{array}$ \\
\hline 2 & $\begin{array}{l}\text { Selangor } \\
\text { 14 April 1960 - 1 September 1960 } \\
\text { Seri Paduka Baginda Almarhum Sultan Hisamuddin Alam } \\
\text { Shah ibni Almarhum Sultan Alaeddin Sulaiman Shah } \\
\text { (13.5.1898-1.9.1960) }\end{array}$ \\
\hline 5 & $\begin{array}{l}\text { Perlis } \\
21 \text { September 1960 - 20 September 1965 } \\
\text { Seri Paduka Baginda Almarhum Tuanku Syed Putra Alhaj ibni } \\
\text { Almarhum Syed Hassan Jamalullail } \\
\text { (25.11.1920-16.4.2000) }\end{array}$ \\
\hline \multirow{5}{*}{4} & $\begin{array}{l}\text { Terengganu } \\
21 \text { September 1965 - 20 September 1970 } \\
\text { Seri Paduka Baginda Almarhum Tuanku Ismail Nasiruddin } \\
\text { Shah ibni Almarhum Sultan Zainal Abidin } \\
\text { (24.1.1907-20.9.1979) } \\
\text { Kedah } \\
\text { 21 September 1970 - 20September 1975 } \\
\text { Seri Paduka Baginda Almarhum Al-Sultan Almu'tasimu Billahi } \\
\text { Muhibbudin Shah ibni Almarhum Sultan Badlishah } \\
\text { (Born in 28.11.1927) }\end{array}$ \\
\hline
\end{tabular}




\begin{tabular}{|c|c|}
\hline 7 & $\begin{array}{l}\text { Pahang } \\
26 \text { April } 1979 \text { - } 25 \text { April } 1984 \\
\text { Seri Paduka Baginda Sultan Haji Ahmad Shah Al- } \\
\text { Musta'in Billah ibni Almarhum Sultan Abu Bakar } \\
\text { Ri'Ayatuddin Al-Mu'adzam Shah } \\
\text { (Born in 24.10.1930) }\end{array}$ \\
\hline 8 & $\begin{array}{l}\text { Johor } \\
26 \text { April - } 1984 \text { - } 25 \text { April } 1989 \\
\text { Seri Paduka Baginda Almarhum Sultan Mahmud } \\
\text { Iskandar Alhaj ibni Almarhum Sultan Ismail al-Khalidi } \\
(8.4 .1932-22.1 .2010)\end{array}$ \\
\hline 9 & $\begin{array}{l}\text { Perak } \\
26 \text { April } 1989 \text { - } 25 \text { April } 1994 \\
\text { Seri Paduka Baginda Almarhum Sultan Azlan } \\
\text { Muhibbudin Shah ibni Almarhum Sultan Yussuf Izzudin } \\
\text { Shah Ghafaru'llahullahu } \\
\text { (Born in 1928) }\end{array}$ \\
\hline 10 & $\begin{array}{l}\text { Negeri Sembilan } \\
26 \text { April } 1994 \text { - } 25 \text { April } 1999 \\
\text { Seri Paduka Baginda Almarhum Tuanku Ja'afar ibni } \\
\text { Almarhum Tuanku Abdul Rahman } \\
(19.7 .1922-27.12 .2008)\end{array}$ \\
\hline 11 & $\begin{array}{l}\text { Selangor } \\
26 \text { April } 1999 \text { - } 21 \text { November } 2001 \\
\text { Seri Paduka Baginda Almarhum Sultan Salahuddin Abdul } \\
\text { Aziz Shah ibni Almarhum Sultan Sir Hisamuddin Alam } \\
\text { Shah (26.4.1999-27.12.2008) }\end{array}$ \\
\hline 12 & $\begin{array}{l}\text { Perlis } \\
13 \text { December } 2001 \text { - } 12 \text { December } 2006 \\
\text { Seri Paduka Baginda Tuanku Syed Sirajuddin ibni } \\
\text { Almarhum Tuanku Syed Putra } \\
\text { (Born in 17.5.1943) }\end{array}$ \\
\hline
\end{tabular}




\begin{tabular}{|l|l|}
\hline 13 & Terengganu \\
& 13 December 2006 - 12 December 2011 \\
& $\begin{array}{l}\text { Seri Paduka Baginda Al-Watiqu Billah,Tuanku Mizan } \\
\text { Zainal Abidin ibni Almarhum Sultan Mahmud } \\
\text { Al-Muktafi Billah Shah } \\
\text { (Born in 22.1.1962) }\end{array}$ \\
\hline 14 & $\begin{array}{l}\text { Kedah } \\
\text { Seri Paduka Baginda Al-Sultan Almu'tasimu Billahi Muhibbudin Tuanku } \\
\text { Alhaj Abdul Halim Mu'adzam ShAh ibni Almarhum Sultan Badlishah } \\
\text { (Born in 28.11.1927) }\end{array}$ \\
\hline
\end{tabular}

\section{FINDING}

"What is the specific style for formal ceremonial coronation attire of Seri Paduka Baginda Yang di-Pertuan Agong? Finding, the styles for formal ceremonial coronation attire of Seri Paduka Baginda Yang di-PertuanAgong are in two styles. The first and second Seri Paduka Baginda Yang di-Pertuan Agong wore a complete set of "Baju Kurung/Baju Melayu cekak musang". Both styles are complete from the headdress until to the bottom accessories. The headdress for the first Agong, Seri Paduka Baginda AlmarhumTuanku Abdul Rahman ibniAlmarhumTuanku Muhammad (31.8.1957-1.4.1960) is in "dendam tak sudah" style. The style of 'dendam tak sudah' is originated from the Negeri Sembilan. The second Seri Paduka Baginda Yang Dipertuan Agong, Seri Paduka Baginda Almarhum Sultan Hisamuddin Alam Shah ibniAlmarhum Sultan Alaeddin Sulaiman Shah (14.4.1960-1.9.1960), Tuanku sultan of Selangor. Tuanku also wear a complete set of Baju Kurung cekak Musang in the same material from head to toe. The difference of both styles is on the headdress. The second Seri PadukaBaginda Yang di- PertuanAgong wore a tengkolok diraja in "setanjak balung raja" folded. This represents the Selangor state style of tengkolok or "solek", unfortunately Tuanku had died before his throne ceremonial.

The front side of the headdress "tengkolok", compliment with the national symbol of a crescent and eleven pointed stars brooch. Tuanku wore a full set of baju kurung cekak musang with a pair of pants with the same material. At the fastening front part of the baju kurung, it is included with five buttons. Besides, tuanku also wore a samping in "dagang luar" style neatly fasten with a big size royal waist buckle "pending di- raja" with national symbol at the center part. Other accessories include, a short royal keris "keris pendik di-raja" and he also wore an honor of Darjah Utama Seri Mahkota Negara (D.M.N) complete with breast stars, a yellow sash and badge. According to the interview with Sulaiman Ahmad (2016), the placement for the breast stars and its' measurement is following the protocol and etiquette. The placement call as the diamond shape, 
start at the middle parts, followed by the left side. The placement of breast star is depend on the total of breast stars that Seri Paduka Baginda Yang di-Pertuan Agong want to wear for that particular occasions.

The ceremonial coronation attire for Seri Paduka Baginda Yang di-Pertuan Agong style had change from wearing the full set of Baju Kurung cekak musang to Muskat starting from the third Seri Paduka Yang di-PertuanAgong, Seri Paduka Baginda Almarhum Tuanku Syed Putra Alhaj ibni Almarhum Syed Hassan Jamalullail (21.9.1960-20.9.1965). Tuanku wore a black suit of Muskat with royal yellow songket of Tengkolok and samping. Tuanku also wore a black trouser with golden thread "tekat tuji" that being embellish to the hemline of the trouser in similar design of the muskat.

The following Seri Paduka Baginda Yang di-Pertuan Agong the forth, Seri Paduka Baginda Almarhum Tuanku Ismail Nasiruddin Shah ibni Almarhum Sultan Zainal Abidin (21.9.1965 - 20.9.1970). The changes occurred at the samping and tengkolok in material of royal yellow songket has is change to black and golden thread songket. Besides, the sash change from the yellow sash into the red sash with bow tie at the end. Move to the sixth Agong, Seri Paduka Baginda Almarhum TuankuYahya Petra ibni Almarhum Sultan Ibrahim (21.9.1975 29.3.1979), tuanku wear the same muskat with red sash but at the top part of the tengkolok di-raja there is a figure of the Kelantan State symbol.

Figure 1: Variation of Maskat style.

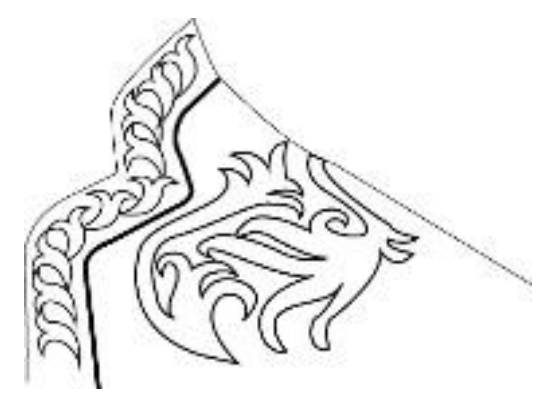

First style

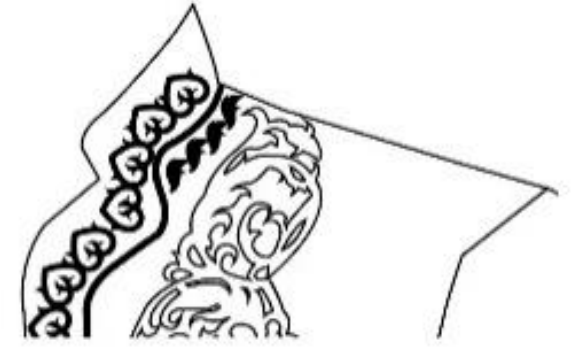

Second style

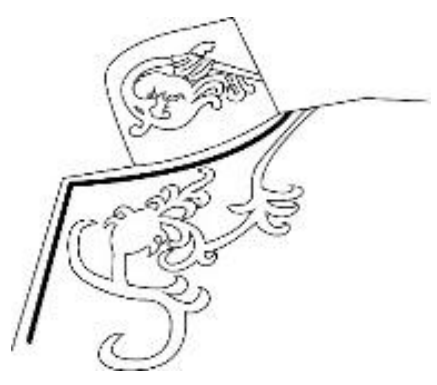

Third style

The seventh Seri Paduka Baginda Yang di-Pertuan Agong, Seri Paduka Baginda Sultan Haji Ahmad Shah Al-Musta'in Billahibni Almarhum Sultan Abu Bakar Ri'Ayatuddin Al- Mua'adzam Shah (26.4.1979 - 25.4.1984) has made major changes on the golden thread muskat design, while the whole style remain the same. The design is in updates version which is in a specific details and intricate design. The hibiscus motif used is in more stylize pattern but still keep the "awan larat" pattern as a whole.

The third changes of the muskat design occurred during the ninth Seri Paduka Baginda Yang di-Pertuan Agong, Seri Paduka Baginda Almarhum Sultan Azlan Muhibbudin Shah ibni Almarhum Sultan Yussuf Izzudin Shah Ghafaru'llahullahu 
(26.4.1989 - 25.4.1994), the golden thread design has finally changed into more simpler design but still maintain the similar element of national flower, the hibiscus and repetition of "awan larat" pattern along the muskat with a single line along the opening part of the muskat. Other than that, the style remains the same. Last but not least, the current Tuanku, Seri PadukaBaginda Yang diPertuan Agong Baginda Al-Sultan Almu'tasimuBillahi Muhibbudin Tuanku Alhaj Abdul Halim Mu'adzam Shah ibni Almarhum Sultan Badlishah (starting from 13.12.2011) have a changes at the sash part from the red sash into the yellow sash. Besides that, the size of the Royal waist buckle plate is smaller compared to the previous size. According to the interview in (2016) the changes occur is due to the certain personal reasons and body size of Tuanku. In compliment with the muskat attire, the set of royal regalia for Seri Paduka Baginda Yang di-Pertuan Agong the tengkolok di-raja, short keris, long keris and royal waist buckle still in the same set back dated from 1957 until 2016. The ceremonial costume explain as an attire that suit with specific ceremony or event, in other words clothing worn for a very special occasions. For example, in academic protocol of graduation ceremony, all participants have to wear the graduation robe, complete set with the mortar board or bonnet. The exploration on the material, style of the garment comes with numbers of motif that embellished the coronation attire. The motifs, form and meanings of the embellishment and tekat tuji are explored in great detail. It is hopes that with greater understanding and appreciation among Malaysians, the art of traditional Malay attires and the exclusive embellishment of gold thread embroidery will be preserved and be maintained as our traditional Malays heritage. The design and idea of the muskat must be agreed by Majlis Raja-Raja. The ideas of golden thread embroidery for the muskat is being agreed by Majlis Raja-raja and being acknowledged by Tan Sri Rais Yatim the Ministry of Culture and Tourism back dated in 1992. From that onwards, the design at the muskat remain until now. Furthermore, the design of the "awan larat" with hibiscus has been recognized as national indication of Malaysia.

\section{CONCLUSION}

Malay outfit born of the growth and development of clothing ancients through the changes process. These are due to the influence bring by the merchants and the surrounding community. Result of this clash, various kinds of textile, variation of clothing, headwear, and accessories appear in Malay. According to Abbas and Norwani (2003) till now the most popular women traditional attires are baju kurung, baju kebaya panjang, baju kebaya pendek, baju kurung kedah, and baju kurung Pahang.

The ceremonial costume explain as an attire that suit with specific ceremony or event, in other words clothing worn for a very special occasions. For example, in academic protocol of graduation ceremony, all participants have to wear the graduation robe, complete set with the mortar board or bonnet. The exploration on the material, style of the garment comes with numbers of motif that embellished the coronation attire. The motifs, form and meanings of the 
embellishment and tekat tuji are explored in great detail. It is hopes that with greater understanding and appreciation among Malaysians, the art of traditional Malay attires and the exclusive embellishment of gold thread embroidery will be preserved and be maintained as our traditional Malays heritage. The design and idea of the muskat must be agreed by Majlis Raja-Raja. The ideas of golden thread embroidery for the muskat is being agreed by Majlis Raja-raja and being acknowledged by Tan Sri Rais Yatim the Ministry of Culture and Tourism back dated in 1992. From that onwards, the design at the muskat remain until now. Furthermore, the design of the "awan larat" with hibiscus has been recognized as national indication of Malaysia.

\section{ACKNOWLEDGEMENT}

My big appreciation and thanks goes to my supervisor in UiTM Shah Alam, Dr. Arba'iyah and to all who had supported me with this research. Thanks a lot for the supports, patience and ideas in assisting me with this research. I also would like to express my gratitude to my family, my appreciation goes to all of respondents and colleagues who had provided the facilities and assistance during interview sessions and data collections, and to those who had lend me their hands, really appreciated that.

\section{REFERENCES}

Zubaidah Syawal, “Busana Melayu,” Kuala Lumpur: Jabatan dan Antikuiti Malaysia, 1994.

Abdul Aziz Bari, "Majlis Raja-raja; Kedudukan dan Peranan dalam Perlembagaan Malaysia." Selangor: Dewan Bahasa dan Pustaka.

Siti Rosnah, “Raja Permaisuri Agong; Payung Mahkota Ibu Pertiwi”. Unknown, 2006.

Radzuan bin Radzi (2016, March 19). "The Seri Paduka Baginda Raja Permaisuri Agong attire." Nor Idayu Ibrahim-intervieweer.

Sulaiman bin Ahmad (2016, May 24) "Muskat Seri Paduka Baginda yang di-Pertuan Agong." Nor Idayu Ibrahim-intervieweer. 